Article

\title{
Hydro-Meteorological Trends in the Yarlung Zangbo River Basin and Possible Associations with Large-Scale Circulation
}

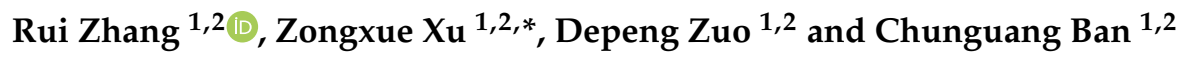 \\ 1 College of Water Sciences, Beijing Normal University, Beijing 100875, China; \\ RUIZhang@mail.bnu.edu.cn (R.Z.); dpzuo@bnu.edu.cn (D.Z.); banchunguang@mail.bnu.edu.cn (C.B.) \\ 2 Beijing Key Laboratory of Urban Hydrological Cycle and Sponge City Technology, Beijing 100875, China \\ * Correspondence: zxxu@bnu.edu.cn; Tel./Fax: +86-10-58801989
}

Received: 30 November 2019; Accepted: 30 December 2019; Published: 2 January 2020

check for updates

\begin{abstract}
Climate change poses potential challenges to sensitive areas, such as high-elevation regions. The Yarlung Zangbo River (YLZR) basin is located in the southeast of the Qinghai-Tibetan Plateau. It contains large amounts of snow and numerous glaciers that are vulnerable to climate change. Based on daily observational data at 17 meteorological stations in and around the YLZR basin during 1957-2015, the variability of precipitation, air temperature, and streamflow were analyzed. The nonparametric Mann-Kendall test, Sen's slope estimate method, cross wavelet transform (XWT), and wavelet coherence (WTC) were used to identify the annual seasonal trends. the abrupt changes of precipitation and air temperature, and their associations with large-scale circulation. The results showed that the YLZR basin experienced an overall rapid warming and wetting during the study period, with an average warming rate of $0.33{ }^{\circ} \mathrm{C} / 10$ a and wetting rate of $4.25 \mathrm{~mm} / 10 \mathrm{a}$, respectively. Abrupt change points in precipitation and air temperature occurred around the 1970s and 1990s, respectively. The abrupt change points of three hydrological stations occurred around the late 1960s and the late 1990s, respectively. The precipitation, annual average temperature, and the streamflow of the three hydrological stations were negatively correlated with the Pacific decadal oscillation (PDO) and the multivariate El Niño-Southern Oscillation (ENSO) index (MEI), reaching a significant level of 0.05 .
\end{abstract}

Keywords: precipitation; air temperature; trends; streamflow; large-scale circulation; Yarlung Zangbo River basin

\section{Introduction}

The effects of obvious trends in global warming in recent decades have had significant impacts on global ecological, economic, and health issues [1-5]. Following recent economic growth and enhancement of the awareness of sustainable development, attention toward global environmental issues related to climate change is increasing [6]. Precipitation and air temperature are important indicators of climate change $[7,8]$. For example, global surface precipitation has increased by approximately $2 \%$ during recent decades [9], while global surface air temperature has increased by $0.85^{\circ} \mathrm{C}$ since preindustrial times [10]. Changes in air temperature and precipitation vary widely on regional and global scales because of regional differences in natural resources [11,12]. Shi [13] found that climate changes, including precipitation and air temperature variations, may greatly alter runoff mechanisms. In addition, air temperature and precipitation have major impacts on natural and human systems on local, regional, and national scales [14,15].

The Qinghai-Tibetan Plateau, which is the highest plateau in the world, has an average elevation of over $4000 \mathrm{~m}$. It extends from the Pamirs in the west to the Hengduan Mountains in the east; a distance 
of about $2945 \mathrm{~km}$ [16]. It is the source region of the Yellow River, Yangtze River, and Brahmaputra-Indus River [17], and it is widely known as the "third pole" and the "Asian water tower" [18]. With its unique geographical features, it has a considerable impact on the regional hydrological and energy cycles, as well as a significant effect on the Asian monsoon circulation and even the global climate [19-22].

Previous studies have shown that the air temperature of the Qinghai-Tibetan Plateau has increased by $0.28^{\circ} \mathrm{C} / 10 \mathrm{a}$ in the past 50 years [23]. Precipitation has also shown a trend of slight increase [24]. The Yarlung Zangbo River (YLZR) basin is a regionally important river that flows across the southeast of the Qinghai-Tibetan Plateau. Because of the special geographical location, the YLZR basin is very sensitive to the effects of climate change $[16,25,26]$. The heterogeneous spatial variation of precipitation in the basin is the result of interaction between the Asian monsoon and regional topography [27]. Precipitation in the YLZR basin has considerable temporal variability [28], which is dominated by summer precipitation, although the inter-annual variation of precipitation is significant [29]. Few human activities have been found in the YLZR basin and the natural runoff play an important role in its performance of providing water resources. The runoff inter-annual oscillations and its response to climatic fluctuations in the middle of the YLZR basin played an essential role in the runoff variations in the middle of the YLZR basin, and the runoff had a positive correlation with precipitation [30]. The main periods of runoff in the YLZR basin were about 40-70 and 80-128 months at intermediate and long-term scales, respectively [31]. Although studies for investigating the hydro-meteorological changes over the YLZR basin are available in the literature, few can be found for exploring the trends of the runoff associated with large-scale circulation.

Changes in regional air temperature have considerable impacts on the snow cover and glaciers within the YLZR basin [32-34], which in turn affects the water resources of the basin [30]. In recent decades, the air temperature within the YLZR basin has shown a significant trend of increase [16]. In addition, the particularities of the geographical location and regional terrain are important for understanding the radiation balance, energy budget, and water cycle of the YLZR basin [28]. Given the increased attention toward climate change, a better understanding of its effects in the YLZR basin requires comprehension of the spatiotemporal variabilities of precipitation and air temperature and their possible causes [35].

Studies have shown that the spatiotemporal characteristics of the variation of summer precipitation in China are influenced by the East Asian summer monsoon (EASM) [36]. However, the El Niño-Southern Oscillation (ENSO) also has an effect on the EASM [37]. Many studies have found that climate anomalies in certain regions of China are influenced by ENSO, the Pacific decadal oscillation (PDO) [38], Atlantic multi-decadal oscillation (AMO) [39], North Atlantic oscillation (NAO) [40], and the East Atlantic/Western Russia (EA/WR) teleconnection pattern [41]. Previous studies have shown that positive (negative) phases of the AMO coincide with warm (cold) phases in China [42]. In southwestern China, the AMO is closely related to air temperature reconstruction on the decadal scale $[43,44]$. It has impact on monsoon precipitation by changing the heat source and the air temperature of the Qinghai-Tibetan Plateau [45]. The EA/WR teleconnection has influence on air temperature and precipitation in southwestern China [46]. During the past 600 years, the NAO, PDO, and ENSO could have played important roles to determine the amount of precipitation in southeastern parts of the Qinghai-Tibetan Plateau, and they might have affected the surface air temperature [47,48].

The main objective of this study was to identify the presence of long-term hydroclimatic changes, analyzing the hydroclimatic variability, detecting whether there exists any significant trends in the YLZR basin and exploring possible associations with large-scale circulation. The study aimed to identify the change point time of hydroclimatic variables. The results could provide reliable information that supports both better understanding of the spatiotemporal variation of water resources in the YLZR basin and improvement of regional water resources management. 


\section{Materials and Methods}

\subsection{Study Area Description}

The YLZR $\left(27^{\circ} 80^{\prime}-31^{\circ} 02^{\prime} \mathrm{N}, 81^{\circ} 09^{\prime}-97^{\circ} 10^{\prime} \mathrm{E}\right)$, which is one of the most important rivers in China, originates at the Gyima Yangzoin Glacier (Figure 1). Influenced by the geographical location and topography of the Qinghai-Tibetan Plateau, precipitation in the YLZR basin varies substantially between upstream and downstream areas. The annual average precipitation over the basin is $428.7 \mathrm{~mm}$ [49]. The upstream region, which is located within the frigid zone, has a mean annual precipitation of $<300 \mathrm{~mm}$. The midstream region has a continental climate with an annual precipitation of 300-600 $\mathrm{mm}$. The downstream region has a maximum annual precipitation of $>2000 \mathrm{~mm}$ [19]. The annual average air temperature in the high-elevation areas is $0-3{ }^{\circ} \mathrm{C}$, whereas it is about $5-9{ }^{\circ} \mathrm{C}$ in the middle reaches. The monthly average highest (lowest) air temperature of the downstream watershed is between 10 and $17(-2$ and -17$){ }^{\circ} \mathrm{C}$. The basin area is $2.42 \times 105 \mathrm{~km}^{2}$ and its length is $2229 \mathrm{~km}$. With an average elevation of $>4600 \mathrm{~m}$, the YLZR basin is one of the highest river basins in the world. The average annual runoff is $1.39 \times 108 \mathrm{~m}^{3}[16,19]$. The YLZR basin lies within the regions of Lhasa, Shigatse, Shannan, Ngari, Nagqu, and Qamdo and it incorporates 41 counties. The basin is considered a reference area for studying both the change and vulnerability of ecosystems in response to the effects of climate change [50].

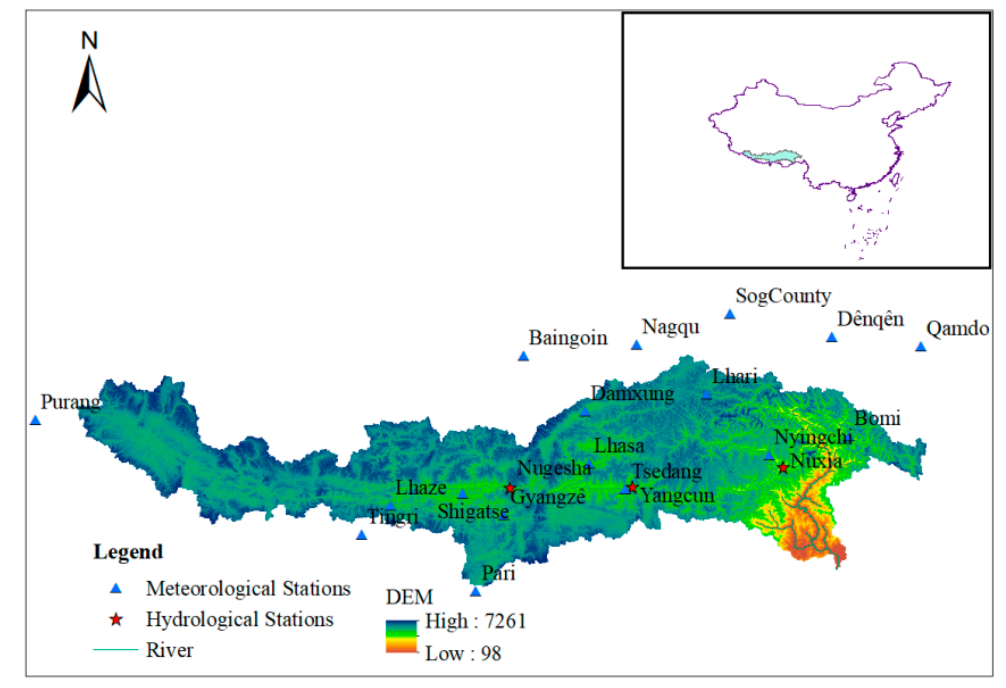

Figure 1. Location of the Yarlung Zangbo River (YLZR) basin and hydro-meteorological stations.

\subsection{Data Description}

Observed daily precipitation and air temperature data are available from the National Meteorological Information Center of China (http://data.cma.cn). The dataset has been subjected to strict quality control by the National Meteorological Information Center, which has included the identification of outliers, internal consistency checks, spatial and temporal consistency checks, and correction of suspicious and erroneous data [51]. This study selected 17 stations located in and around the YLZR basin for analysis. The elevation of the selected meteorological stations was in the range of 2736-4900 $\mathrm{m}$. Several of the stations had some missing data records during the early part of the study period (i.e., 1957-1960), accounting for about $0.33 \%$ of all the daily precipitation (or air temperature) data. Gaps in the precipitation data record were filled through spatial interpolation using the ordinary Kriging method [52]. Missing air temperature data were replaced based on data from well-correlated neighboring stations using linear regression [53]. The streamflow data are available from the Tibet Hydrology and Water Resources Investigation Bureau. This study selected three stations for analysis. 
The locations of the selected meteorological stations are shown in Figure 1. In this study, March, April, and May were defined as spring; June, July, and August were defined as summer; September, October, and November were defined as autumn, and December, January, and February, into the following year, were defined as winter.

In this paper, six kinds of atmospheric circulation indices were selected for analysis. The EASM index (EASMI) was available for direct download from the following website of Professor Li J.P.: http://ljp.gcess.cn/dct/page/65577. The multivariate ENSO index (MEI) was used to characterize ENSO events during 1957-2015. The data of the MEI, AMO, and EA/WR were obtained from the following website: http://www.esrl.noaa.gove/psd/enso/mei/index.html. The data of the NAO is available for download from the following website: https:/www.cpc.ncep.noaa.gov/products/ precip/CWlink/MJO/climwx.shtml, and the PDO is available for download from http://research. jisao.washington.edu/data_sets/. The Indian Ocean Dipole (IOD) is available for download from http://www.jamstec.go.jp/aplinfo/sintexf/iod/dipole_mode_index.html.

\subsection{Mann-Kendall Test}

The time series of precipitation and air temperature data were subjected to the Mann-Kendall (M-K) test to detect any significant trends [54,55]. The M-K test has particular applicability to hydrological and meteorological data with non-normal distribution. It is also often used to detect trends in the frequency of precipitation and drought under the influence of climate change. In the $\mathrm{M}-\mathrm{K}$ test, the null hypothesis $\left(\mathrm{H}_{0}\right)$ assumes that there is no significant increased or decreased trend in the time series, while the time series has a significant variation trend based on the alternative hypothesis. The test statistic $S$ can be defined as follows:

$$
S=\sum_{\mathrm{i}=1}^{n-1} \sum_{j=\mathrm{i}+1}^{n} \operatorname{sign}\left(X_{j}-X_{i}\right)
$$

In the above equation, $\operatorname{sign}()$ is the sign function; $X_{i}$ is a time series from $i=1,2,3, \ldots, n-1$ and $X_{j}$ is another time series from $j=I+1, \ldots, n ; X_{j}$ is greater than $X_{i} ; n$ is the data set record length. The test statistic $(S)$ is described by the Equation (2):

$$
\operatorname{sign}\left(x_{j}-x_{\mathrm{i}}\right)=\left\{\begin{array}{c}
+1 \text { for }\left(x_{j}-x_{i}\right)>0 \\
0 \text { for }\left(x_{j}-x_{i}\right)=0 \\
-1 \text { for }\left(x_{j}-x_{i}\right)<0
\end{array}\right\}
$$

If the data set is identically and independently distributed, then the mean of $S$ is zero and the variance of $S$ is Equation (3):

$$
\operatorname{Var}(S)=\left[n(n-1)(2 n+5)-\sum_{t} t(t-1)(2 t+5)\right] / 18,
$$

where $n$ is the length of the data set and $t$ is the extent of any given time and represents the sum over all ties. The statistic $Z$, which is the $\mathrm{M}-\mathrm{K}$ test value, can be calculated as shown in Equation (4):

$$
\left\{\begin{array}{l}
Z=\frac{S-1}{\sqrt{\operatorname{var}(S)}} S>0 \\
Z=0 S=0 \\
Z=\frac{S+1}{\sqrt{\operatorname{var}(S)}} S<0
\end{array}\right.
$$

When $Z$ is $-1.96 \leq Z \leq 1.96$, the null hypothesis $\left(H_{0}\right)$ is accepted, which indicates that there is no obvious trend. If $Z>0$, it is increasing, whereas if $Z<0$, it is decreasing. An absolute value of $Z$ 
of greater than or equal to $1.28,1.64$, and 2.32 means it has passed the significance test of $90 \%, 95 \%$, and $99 \%$ reliability, respectively.

\subsection{Sen's Slope (SS) Estimator}

Sen's slope estimate is a nonparametric test proposed and developed by Sen [56], which estimates the slope of the trend of $N$ pairs of data in $n$ samples. It can be computed using Equation (5):

$$
Q_{i}=\frac{x_{j}-x_{k}}{j-k} \text { for } i=1,2, \cdots N
$$

In the above equation, $x_{j}$ and $x_{k}$ are the time series values of the $j$-th and $k$-th samples, respectively; $(j>k)$ and $N=\frac{n(n-1)}{2}$.

By arranging the values of $Q_{i}$ from small to large, the median value of the Sen's slope estimate can be derived as follows:

$$
Q_{\text {med }}=\left\{\begin{array}{l}
Q_{[(N+1) / 2]} \text { for } N \text { is odd } \\
\frac{Q_{[N / 2]}+Q_{[(N+2) / 2]}}{2} \text { for } N \text { is even }
\end{array}\right.
$$

In Equation (6), a value of $Q_{\text {med }}>0$ indicates that the test statistics have a trend of increase; otherwise, it indicates a trend of decrease.

\subsection{Abrupt Change Test}

By constructing an order column, the $\mathrm{M}-\mathrm{K}$ test can be used to test for sequence mutations, as in the following equations:

$$
\begin{gathered}
S_{k}=\sum_{i=1}^{k} \sum_{j}^{i-1} a_{i j}(k=2,3,4, \cdots, n), \\
a_{i j}=\left\{\begin{array}{ll}
1 & X_{i}>X_{j} \\
0 & X_{i}<X_{j}
\end{array} \quad 1 \leq j \leq i\right.
\end{gathered}
$$

The statistical variable can be defined as in Equation (9):

$$
\begin{gathered}
U F_{k}=\frac{\left[S_{k}-E\left(S_{k}\right)\right]}{\sqrt{\operatorname{Var}\left(S_{k}\right)}}(k=1,2, \cdots, n), \\
E\left(S_{k}\right)=k(k+1) / 4 ; \operatorname{Var}\left(S_{k}\right)=k(k-1)(2 k+5) / 72
\end{gathered}
$$

Here, $U F_{k}$ is the standard normal distribution. For significance level $\alpha$, if $\left|U F_{k}\right|>U_{\alpha / 2}$, it indicates an obvious change in the trend of the sequence. By arranging time series $X$ in reverse order, the calculation can be performed according to the above formula and Equation (11) can be considered:

$$
U B_{k}=-U F_{k}{ }^{\prime}, k^{\prime}=n+1-k\left(k^{\prime}, k=1,2, \cdots, n\right)
$$

A derived value of $U F_{k}>0$ indicates that the sequence shows an upward trend, whereas a value of $U F_{k}<0$ indicates that the sequence shows a downward trend. If the two curves of $U F_{k}$ and $U B_{k}$ intersect at a point between the critical lines, the point at which they intersect is deemed the beginning of the mutation.

\subsection{Selection of Large-Scale Circulation Indices}

Principal component analysis (PCA) is a statistical method and has been widely used in previous studies $[57,58]$. It uses orthogonal transformation to transform the observed values of a set of possibly related variables into a set of linear independent variables. This paper used this method to select several dominant signals of the atmospheric circulation index that have influence on the YLZR basin. 
The principal components (PCs) of most signals were chosen as an alternative to explain the relationship between temperature or precipitation and atmospheric circulation. The detailed information of PCA was referred to several previous studies $[59,60]$.

\subsection{Wavelet Transform}

Wavelet transform has been widely used in the fields of hydrology and geophysics [61-64]. In hydrology, wavelet transform was successfully applied for time series forecasting, and it was also used to identify the trends and periodicities in hydrological variables in different regions [61-64]. In this paper, we calculate the cross wavelet transform (XWT) and wavelet coherence (WTC) of air temperature or precipitation and large-scale indices by $[65,66]$. The XWT identifies the common power, whereas WTC gives a measure of local correlation between two time series in the time-frequency plane. The relative phase between the two time series can also be discerned from the XWT or WTC [67].

\section{Results Analysis}

\subsection{Annual Average Precipitation and Air Temperature}

Based on meteorological data acquired from 17 stations (1957-2015) in the YLZR basin, the annual average precipitation and annual average air temperature were analyzed using Sen's slope (Figure 2). Generally, the average air temperature of the YLZR basin increased from upstream areas to downstream regions, but with some notable regional characteristics. In northern parts of the midstream area, the increased rate of air temperature reached its highest. The increased rate of air temperatures around the Lhasa station was the highest throughout the basin and urban built-up land use was the main land use type near the station. The increased rate of annual precipitation in the YLZR basin increased gradually from upstream areas to downstream regions. The annual precipitation and annual average air temperature increased throughout the basin.

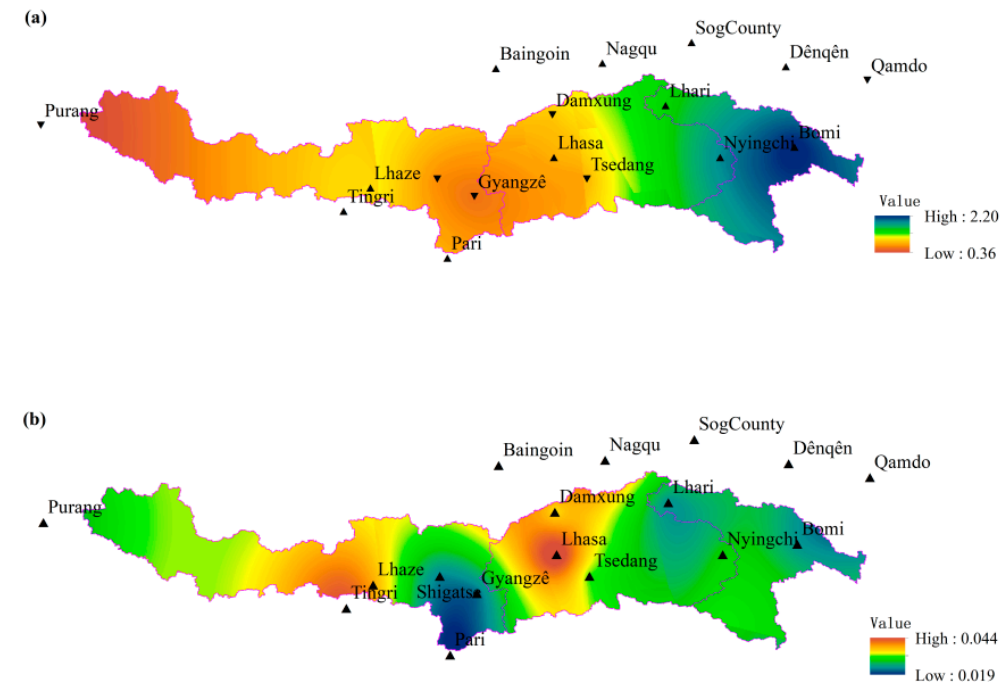

Figure 2. Sen's slope of (a) the annual average precipitation; (b) annual average air temperature.

\subsection{Temporal Variability of Precipitation and Air Temperature}

The results of the analysis of long-term precipitation in the YLZR basin are shown in Figure 3. Annual and seasonal precipitation showed trends of increase during 1957-2015. The highest (lowest) value of annual precipitation was 565.58 (341.89) $\mathrm{mm}$ in 1998 (1959) and the multiyear average was $466.18 \mathrm{~mm}$ (Figure 3a). The rate of increase of spring precipitation was higher than that of annual precipitation (Figure 3b). The lowest (highest) value of summer precipitation was 195.31 (389.74) $\mathrm{mm}$ in 2006 (1998) and the multiyear average was $293.07 \mathrm{~mm}$ (Figure 3c). Autumn precipitation showed slight 
fluctuation and a trend of increase (Figure 3d). The lowest (highest) value was 52.17 (131.85) $\mathrm{mm}$ in 1958 (1990) and the multiyear average was $91.76 \mathrm{~mm}$. Precipitation in winter showed an obvious trend of increase (Figure 3e). The slope of the line of its linear growth was 0.54 ; the lowest (highest) value was 2.47 (16.77) $\mathrm{mm}$ in 1960 (1996). Precipitation in summer represents the largest proportion (i.e., about $60 \%$ ) of annual precipitation. A change in the trend of precipitation in summer and autumn in the last 60 years was not obvious, but the trend of increase of precipitation in spring and winter was significant, although the rate of increase of precipitation in spring was lower than in winter. The increase of annual precipitation was mainly attributable to the increase of precipitation in spring and winter. The YLZR basin experienced a wetting trend during 1957 2015 and the average wetting rate was $4.25 \mathrm{~mm} / 10 \mathrm{a}$.
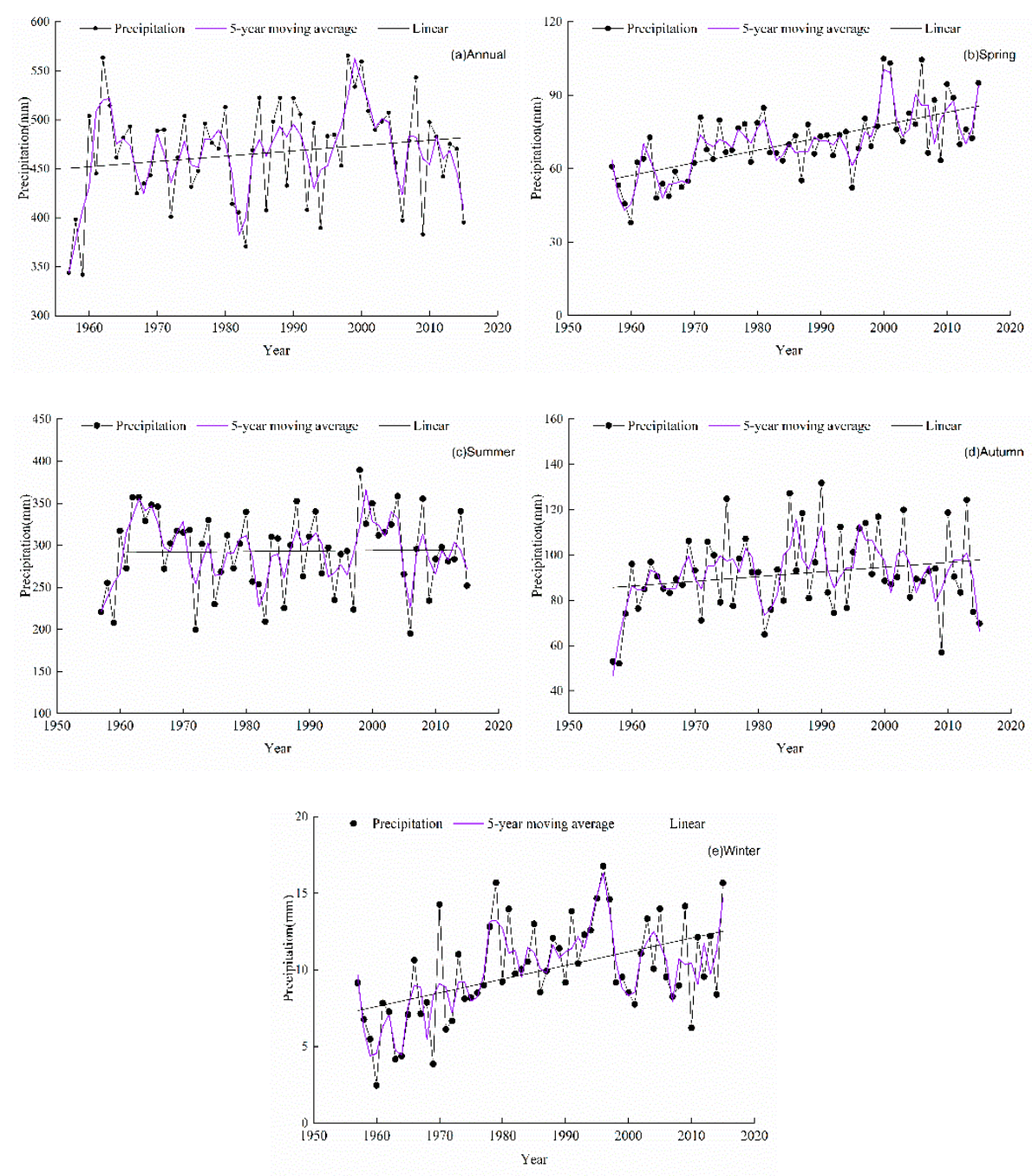

Figure 3. Trends of annual average precipitation and seasonal average precipitation in the YLZR basin from 1957 to 2015.

The results of the analysis of long-term air temperature in the YLZR basin are shown in Figure 4 and both annual and seasonal air temperature showed trends of increase. The average annual, spring, summer, autumn, and winter air temperatures are shown in Figure 4a-e, respectively. The highest (lowest) annual average air temperature was 5.73 (2.72) ${ }^{\circ} \mathrm{C}$, which occurred in 2009 (1962). The highest (lowest) average air temperature in spring was $6.34(3.08)^{\circ} \mathrm{C}$, which occurred in 1999 (1983). The trend of increase of summer average air temperature was lower than that of spring. The highest (lowest) value of summer average air temperature of 13.64 (11.19) ${ }^{\circ} \mathrm{C}$ occurred in 2009 (1976). The highest (lowest) value of average air temperature in autumn of 6.08 (3.10) ${ }^{\circ} \mathrm{C}$ occurred in 2009 (1965). The highest (lowest) value of winter average air temperature of $-1.44(-4.77){ }^{\circ} \mathrm{C}$ occurred in 2006 (1963). Overall, the warming 
trend of both annual and seasonal average air temperature was very significant. In comparison with other seasons, the air temperature increase in winter was most significant. Thus, it is clear that the YLZR basin experienced an overall rapid warming with an average warming rate of $0.33^{\circ} \mathrm{C} / 10$ a.
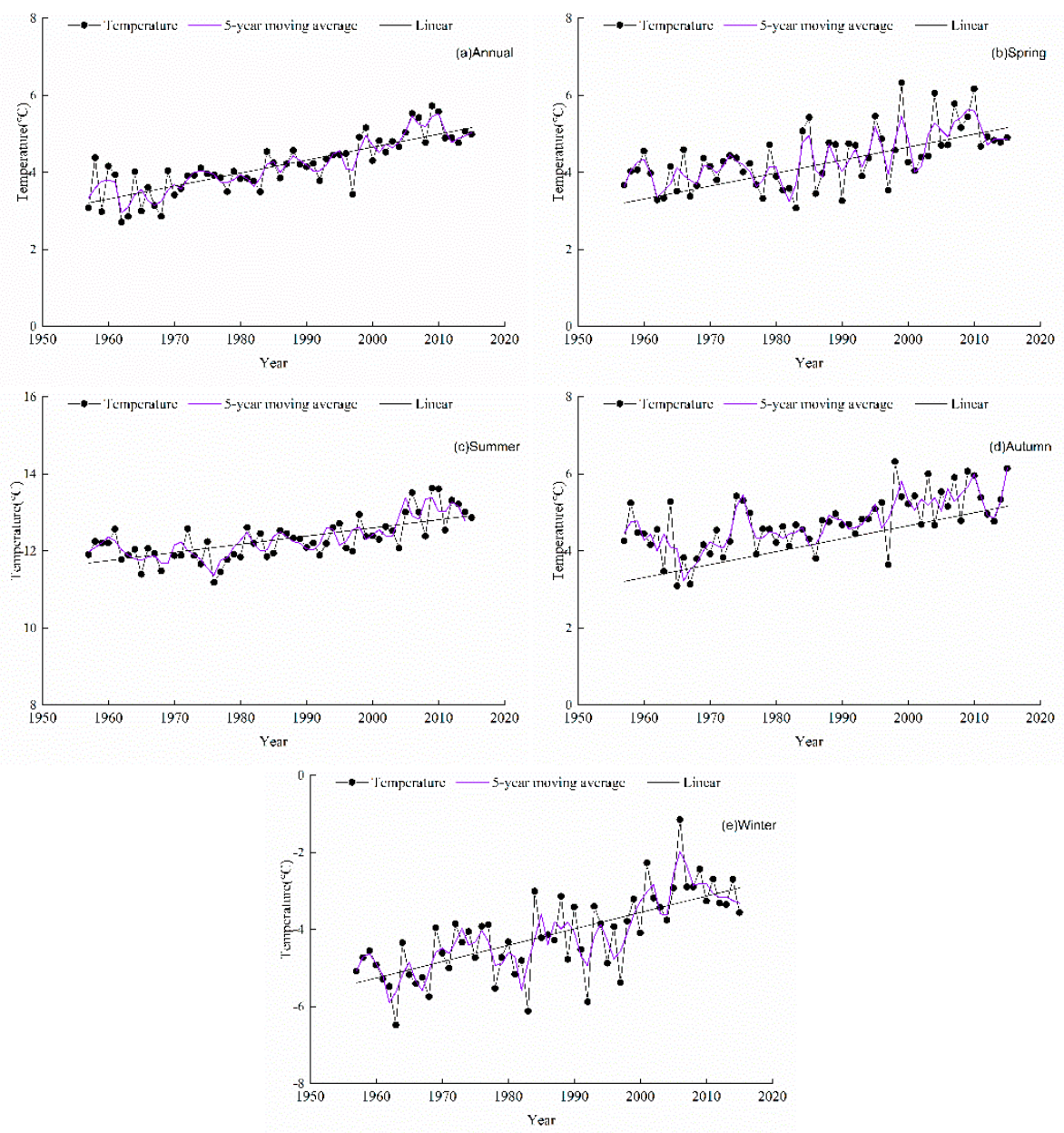

Figure 4. Annual average air temperature and seasonal average air temperature trends in the YLZR basin from 1957 to 2015.

\subsection{Abrupt Changes of Precipitation and Air Temperature in the YLZR Basin}

Climate change refers to the transition of climate from one steady state to another. It occurs when the climate system is forced to cross a threshold and trigger a transition to a new state at a certain rate determined by the climate system [68]. In this study, the $\mathrm{M}-\mathrm{K}$ mutation test was used to determine the annual and seasonal changes in precipitation and air temperature in the YLZR basin. The results of the $\mathrm{M}-\mathrm{K}$ mutation test of annual and seasonal precipitation are shown in Figure 5. The UF and UB curves displayed in the figure were derived from the $\mathrm{M}-\mathrm{K}$ test, and the confidence level was set at $95 \%$ (statistical significance level a = 0.05). In Figure 5, the intersection of the UF and UB curves of annual and seasonal precipitation is within the confidence interval. An abrupt change of annual precipitation occurred in 1960. Seasonally, abrupt changes of precipitation occurred in spring in 1974, summer in 1978 and 1996, autumn in 1960, and winter in 1973. 

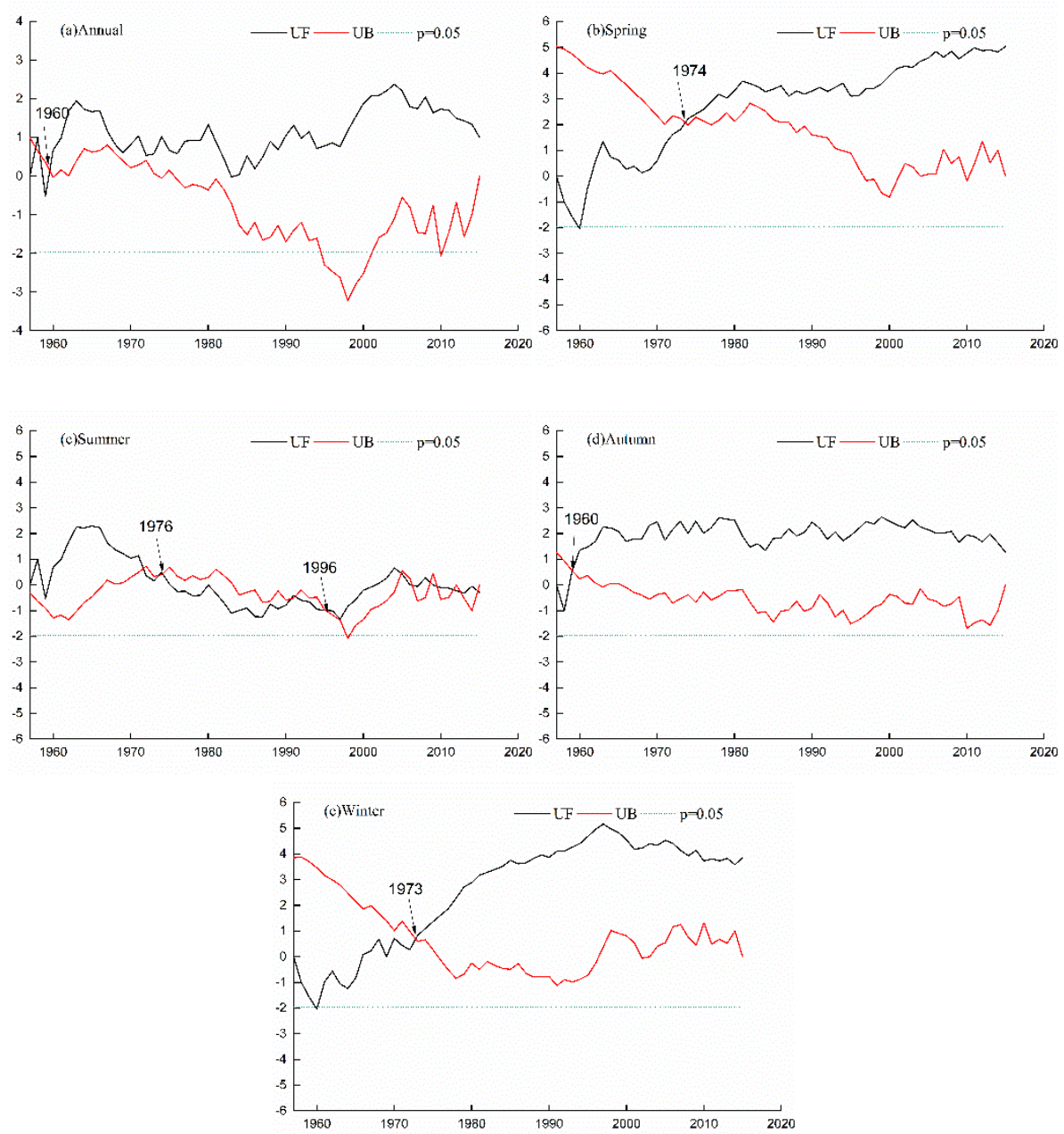

Figure 5. Abrupt change of annual and seasonal precipitation in the YLZR basin during 1957-2015.

The M-K test results of the annual and seasonal average air temperature during 1957-2015 are shown in Figure 6. In comparison with the changes of precipitation, the changes of air temperature are relatively simple. Unlike the annual average air temperature, the average air temperature in each season was within the confidence interval. Analysis based on a moving $t$ test showed that the annual average air temperature changed abruptly in 1989. Seasonally, abrupt changes in air temperature occurred in spring in 1992, summer in 2000, autumn in 1992, and winter in 1993. In the YLZR basin, abrupt changes in annual and seasonal average air temperature occurred around the 1990s.
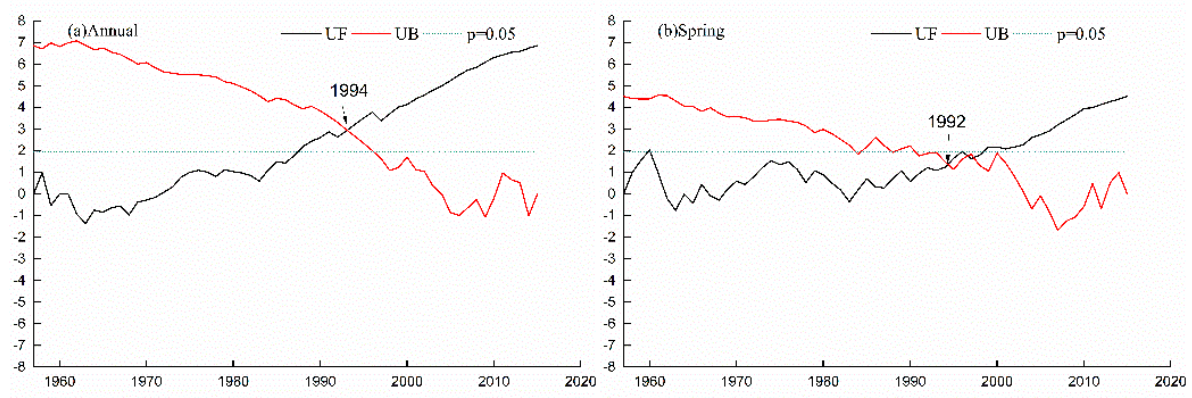

Figure 6. Cont. 


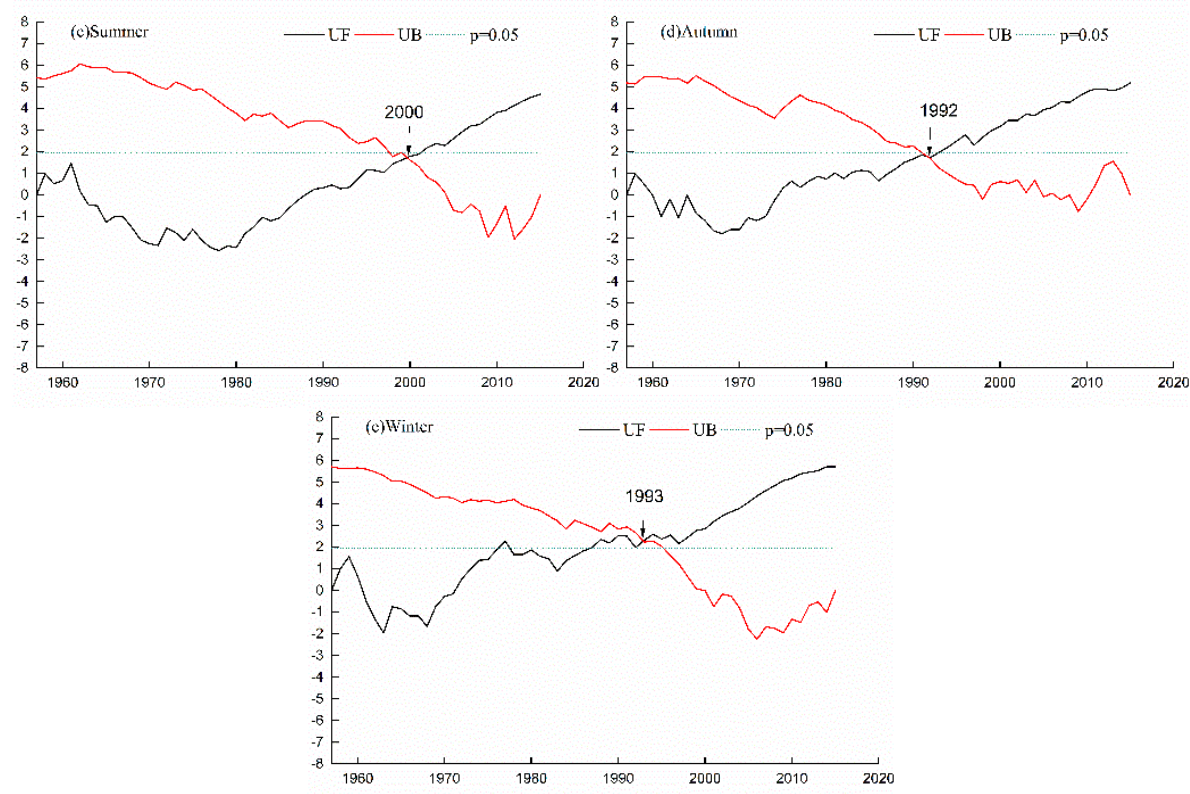

Figure 6. Abrupt change of annual and seasonal air temperature in the YLZR basin during 1957-2015.

\subsection{Synergistic Changes of Precipitation and Air Temperatures}

Previous studies have shown that there might be a weak relationship between global surface air temperature and precipitation [69] and that surface air temperature and precipitation have significant seasonal variability $[11,70]$. Based on the trend rate values $(Z)$ of air temperature and precipitation change on the annual scale, this study multiplied the $Z$ values of the two variables to determine the region with the most significant trend of synchronous change of the two variables.

It can be seen from Figure 7 that the Shigatse, Gyangzê, and Tsedang areas have had a warming-drying trend, mainly distributed in the middle reaches of the YLZR basin, while other areas have had a warming-wetting trend. The warming-wetting trend increased gradually from upstream to downstream reaches of the YLZR basin during 1957-2015.

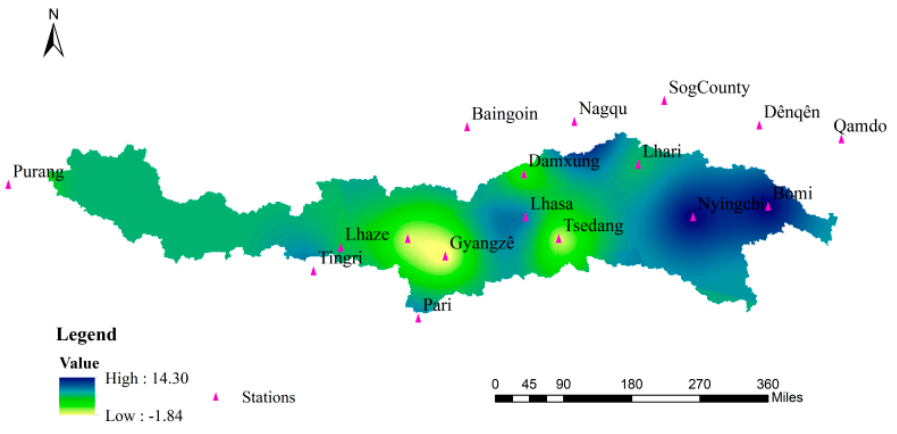

Figure 7. Covariability of the mean air temperature and precipitation of the basin.

\subsection{Streamflow}

Figure 8 showed the streamflow analysis of three hydrological stations in the YLZR basin. Over all, since the late 1960s, the annual streamflow of the three hydrological stations in the river basin has gradually decreased. In the 1970s and 1980s, it was in a stable change period and gradually increased in the late 1990s. In the 21st century, the annual streamflow increased first and then decreased. The three hydrological stations had the same trend. 


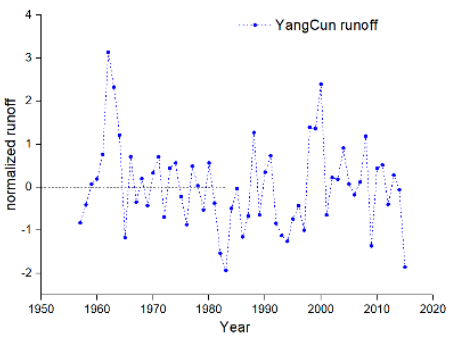

(a)

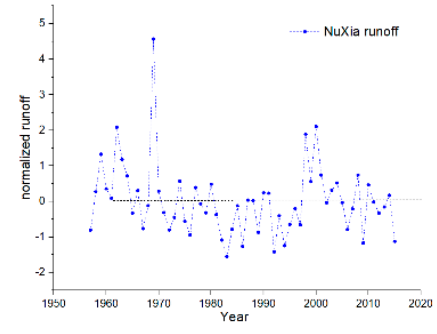

(b)

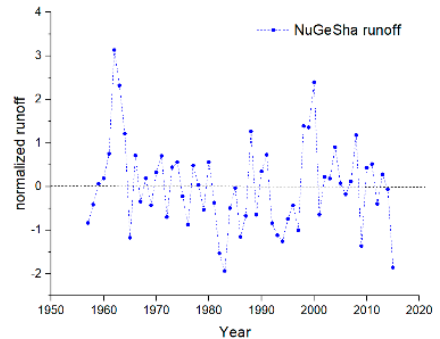

(c)

Figure 8. Streamflow trends for selected stations: (a) Yangcun station, (b) Nuxia station, and (c) Nugesha station in the YLZR basin during 1957-2015.

\subsection{Detection of Change Points in Streamflow Time Series}

The change point analysis indicated several change points at three hydrological stations (Figure 9). The test results of the mean streamflow at three stations showed an upward change that occurred around 1965 and 1967. After 2000, the three hydrological stations exhibited fluctuation change. Between the 1970s and the 1990s, the annual streamflow showed a downward change.
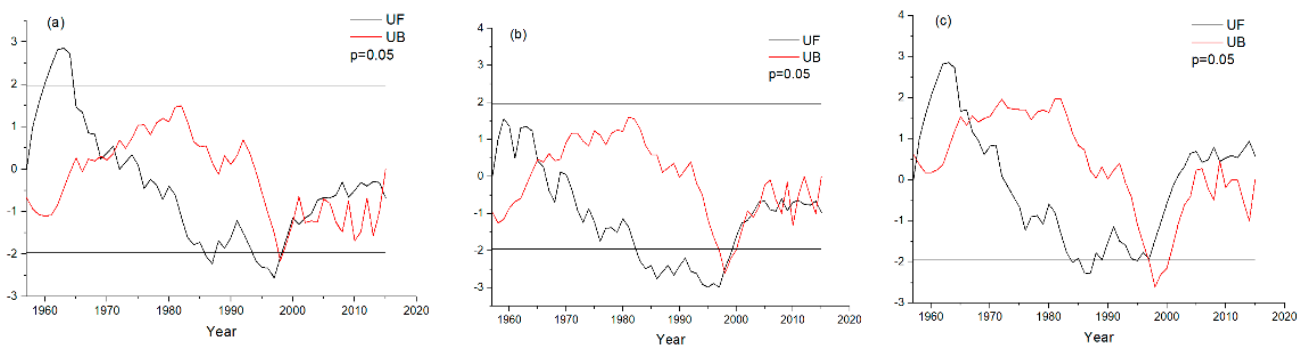

Figure 9. The streamflow change point of the (a) nugesha, (b) nuxia, and (c) yangcun stations in the YLZR basin during 1957-2015.

\subsection{Correlations between the Hydro-Meteorological and Large-Scale Circulations}

In this study, PCA was used to extract the PCs, of which the cumulative variance contribution rate was higher than $85 \%$ from atmospheric circulation indices (Table 1 ). The PCs mainly consist of IOD, PDO, and MEI, which contribute to $88.1 \%$ cumulatively. Therefore, this paper mainly analyzes the influence of these three indexes on precipitation, temperature, and streamflow.

Table 1. Factor loadings and explained variances for large-scale circulation indices in the Yarlung Zangbo River basin during 1957-2015.

\begin{tabular}{cccccccccc}
\hline Component & IOD & NAO & AMO & EAWR & PDO & MEI & SOI & EASMI & $\begin{array}{c}\text { Accumulating } \\
\text { Contribution Rate (\%) }\end{array}$ \\
\hline 1 & 0.078 & 0.191 & -0.023 & 0.166 & 0.494 & 0.589 & -0.580 & -0.056 & 56.0 \\
2 & 0.031 & 0.423 & -0.190 & 0.484 & -0.573 & -0.118 & -0.020 & 0.455 & 72.1 \\
3 & 0.797 & 0.088 & 0.199 & -0.313 & -0.258 & 0.093 & -0.122 & 0.359 & 88.1 \\
\hline
\end{tabular}

Based on the method of XWT and WTC, the time-frequency relationship among precipitation, temperature, streamflow, and atmospheric circulation indices in the YLZR basin during 1957-2015 was analyzed. The XWT and WTC were used to diagnose the similarity between two variables by analyzing the common wave signal between two variables. In this paper, the XWT was used to analyze the correlations among precipitation, air temperature, and atmospheric circulation indices in the high energy spectral region in the time and frequency domain, while the WTC was used to analyze the correlation between them in the low energy spectral region in the time and frequency domain. The XWT is useful for finding the regions in the time-frequency domain with large common power 
between/among the time series, while WTC shows significant coherence of variance processes even though the common power is not large. The results of XWT and WTC of annual precipitation and atmospheric circulation indices in the YLZR basin are shown in Figure 10.
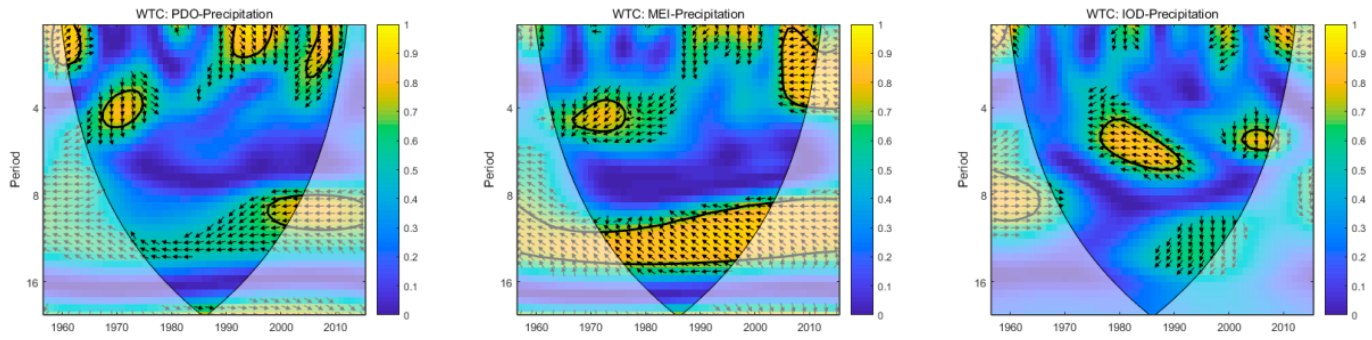

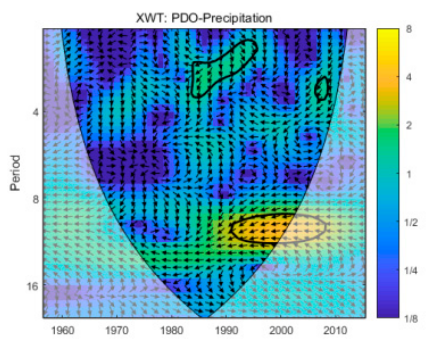

(a)

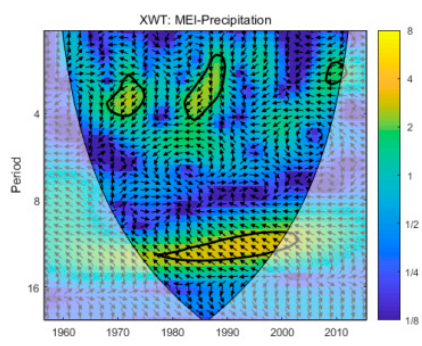

(b)

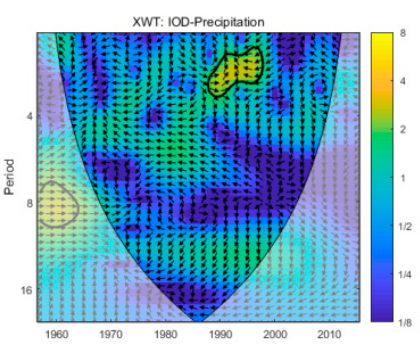

(c)

Figure 10. Wavelet coherence and cross wavelet transform of annual average precipitation with (a) PDO, (b) MEI, (c) IOD (1957-2015). The thick black contours depict the 5\% significance level of local power, relative to red noise, and the black line is the cone of influence. Right-pointing arrows indicate that the two signals are in phase, while left-pointing arrows are for anti-phase signals. Up-pointing (down-pointing) arrows indicate that the precipitation change of the YLZR basin was ahead (backward) of the large-scale circulation indices and was $90^{\circ}$, which meant that the precipitation change of the YLZR basin was one quarter of a cycle earlier (later) than that of the large-scale circulation indices. The unit of the period is a.

According to Figure 10, there was a certain correlation between the annual precipitation of the YLZR basin and the PDO, MEI, and IOD at different time scales, respectively. The annual precipitation was negatively correlated with three indices, reaching a significant level of 0.05 . The PDO had a $1 \sim 4 a$ resonance period with annual precipitation, and the arrows were inclined down, indicating that PDO lagged behind the annual precipitation by 1a around 1970 at a 4a scale. The MEI lagged behind the annual precipitation by $1.5 \mathrm{a}$ around 1970 at a $4 \mathrm{a}$ scale. In the regions of no significant wavelet power, the phase relations were disordered and no clear changing pattern could be identified. It can be seen that the complexity of precipitation was affected by many factors. Although these three indices shared several cycles with precipitation, they were also inconsistent. The MEI had stronger effects on precipitation.

Over the years, the temperature in the YLZR basin also changed. Figure 11 was the cross transform and wavelet coherence of the annual average temperature of the YLZR basin with PDO, MEI, and IOD, respectively. The same as fir precipitation, the annual average temperature was negatively correlated with all three indices, reaching a significant level of 0.05 . The PDO had a $1 \sim 6$ a resonance period with the annual average temperature, and the arrows were inclined to the lower left, indicating that PDO lagged behind the annual average temperature by 2.25a on a scale of $6 \mathrm{a}$. The MEI lagged behind the annual average temperature by $2.25 \mathrm{a}$ on a scale of $1 \sim 6 \mathrm{a}$. The IOD had the same trend with the PDO. It can be seen that the annual average temperature was affected by a variety of factors in different time scales. According to Figures 10 and 11, the three large-scale circulation indices had a greater impact on the temperature of the YLZR basin than on the precipitation. These observations seem to indicate a clear link between the annual average temperature, precipitation, and the three large-scale circulation indices at around the 4-year band, during 1980-1990. 

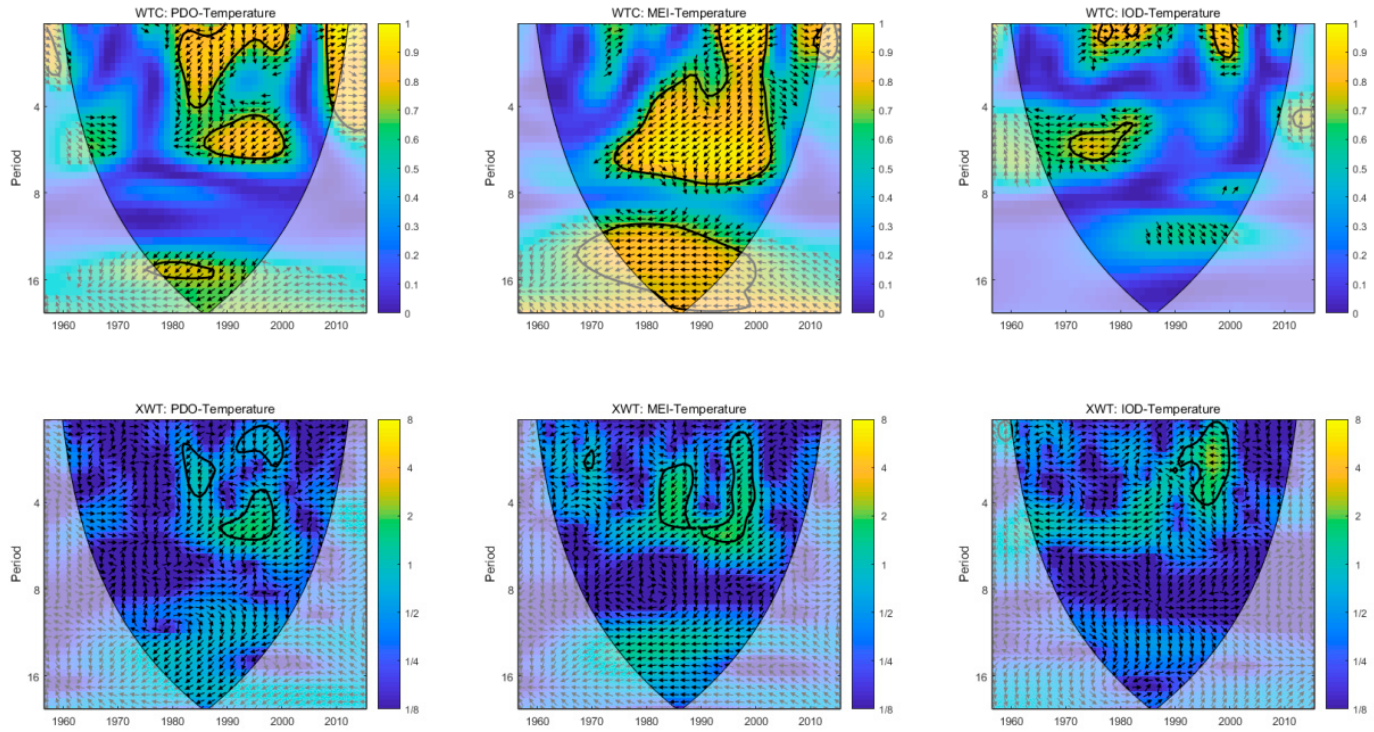

(a)

(b)

(c)

Figure 11. Wavelet coherence and cross wavelet transform of the annual average air temperature with (a) PDO, (b) MEI, and (c) IOD (1957-2015). The meaning in the figure is the same as in Figure 10.

Figure 12 was the cross transform and wavelet coherence of the annual streamflow of the YLZR basin with PDO, MEI, and IOD, respectively. The precipitation was positively correlated with the annual streamflow of three stations, reaching a significant level of 0.05 . The precipitation had a great impact on the discharge of the YLZR basin. There was a high consistency between precipitation and streamflow. These observations seem to indicate a clear link between the streamflow and the three large-scale circulation indices at around the 2-year and 12-year bands during 1980-1990.
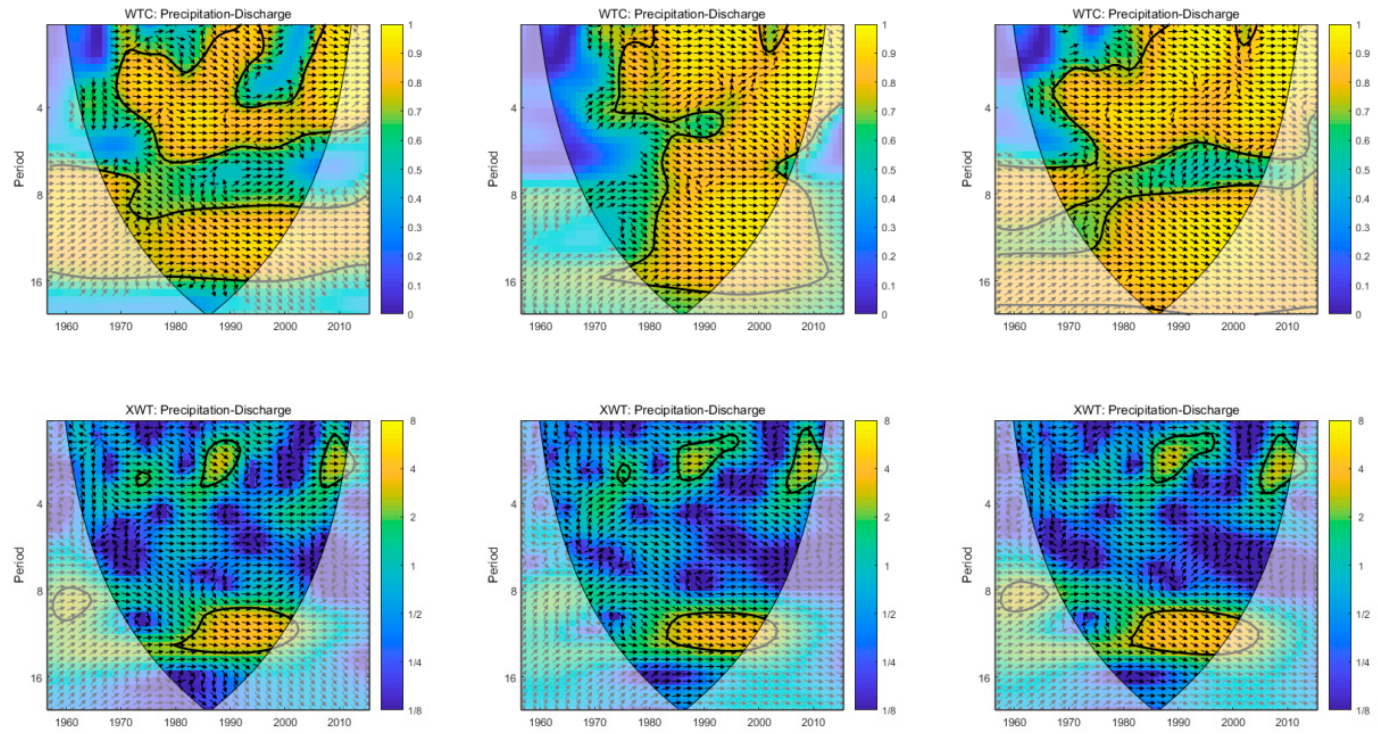

(a)

(b)

(c)

Figure 12. Wavelet coherence and cross wavelet transform of discharge of three hydrological stations with an annual average precipitation (1957-2015). The meaning in the figure is the same as in Figure 10. (a) Nugesha station; (b) Nuxia station; (c) Yangcun station. 
Cross wavelet transform of streamflow of selected hydrological stations in the basin with MEI, PDO, and IOD is shown in Figure 13. Wavelet coherence of streamflow of selected hydrological stations with MEI, PDO, and IOD is shown in Figure 14. Figure 13 shows that the three hydrological stations had similar trends. The streamflow in the basin was negatively correlated with MEI and PDO on a scale of 2-4a. This indicates that, with the increase of MEI and PDO, the precipitation will decrease and the streamflow of the three hydrological stations in the basin will decrease. The relationship between IOD and the runoff was not consistent at different time scales. Figure 14 indicates that, in the low energy spectrum, there was no consistent relationship between the three atmospheric circulation indexes and the streamflow of the three hydrological stations in the basin, and the relationships were different on different time scales. There is no clear changing pattern in the regions of no significant wavelet power.

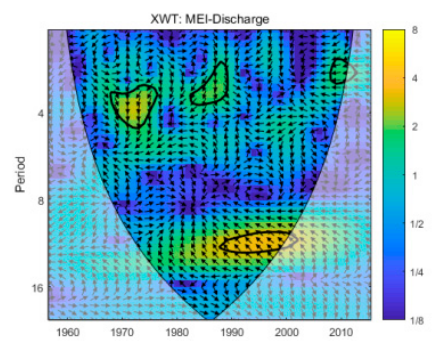

(a1)

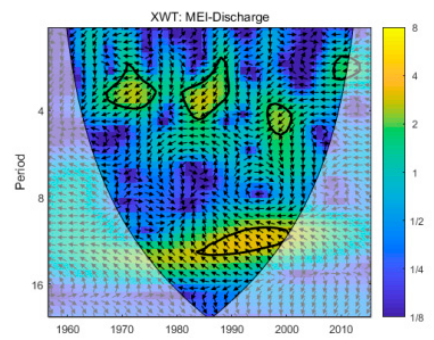

(b1)

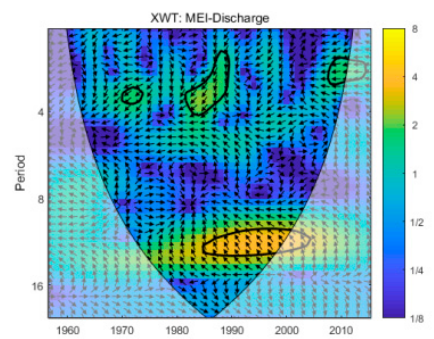

(c1)

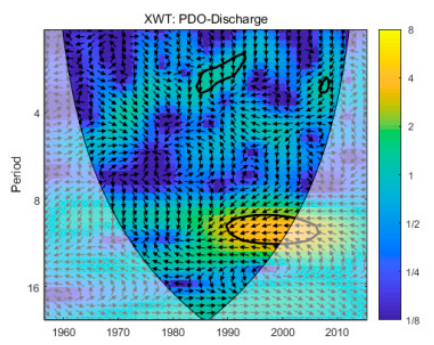

(a2)

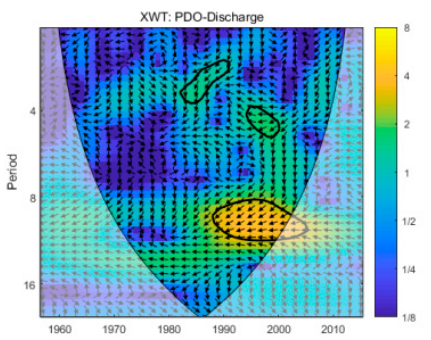

(b2)

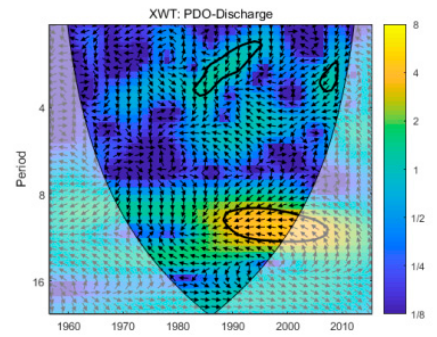

(c2)

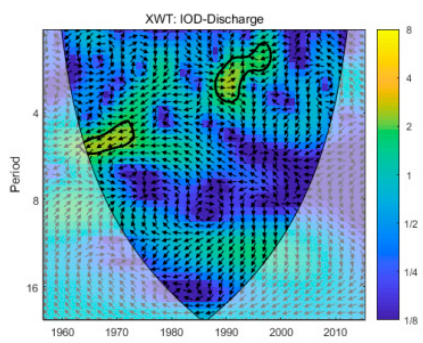

(a3)

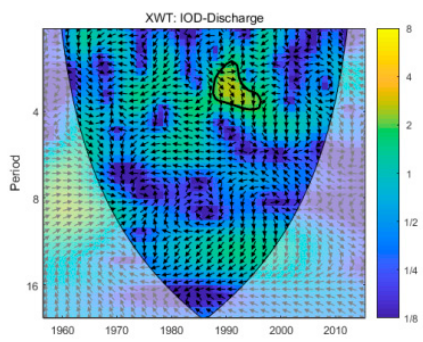

(b3)

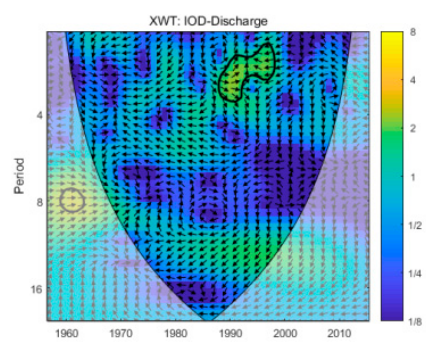

(c3)

Figure 13. Cross wavelet transform of discharge of three hydrological stations with MEI, PDO, and IOD, respectively. ((a1-a3) Nuxia station; (b1-b3) nugesha station; (c1-c3) yangcun station). The meaning in the figure is the same as in Figure 10. 


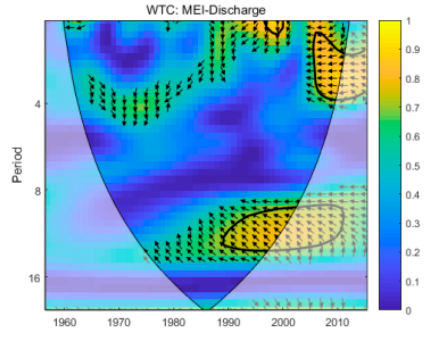

(a1)

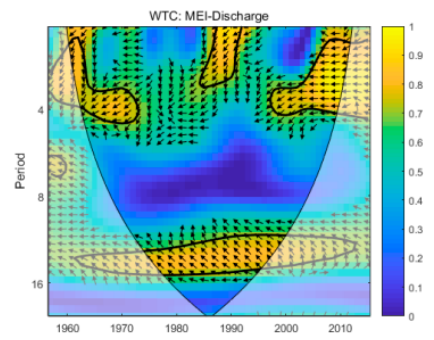

(b1)

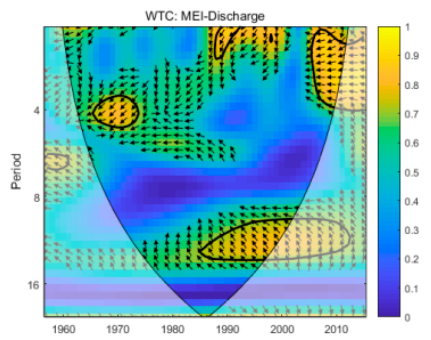

(c1)

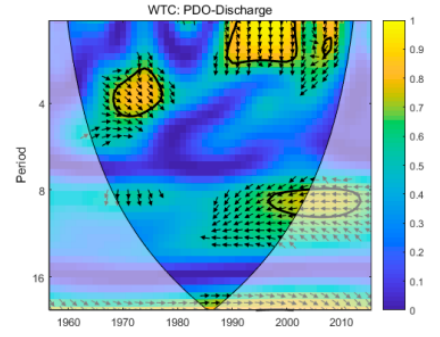

(a2)

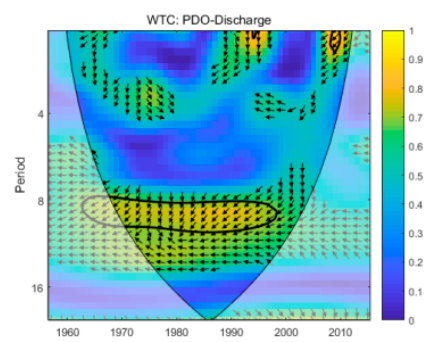

(b2)

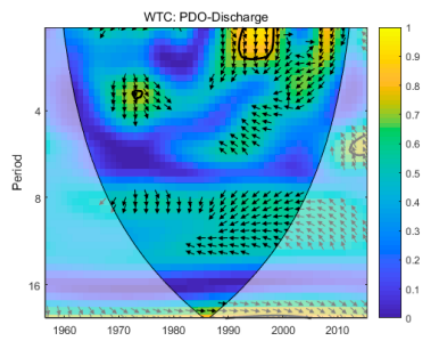

(c2)

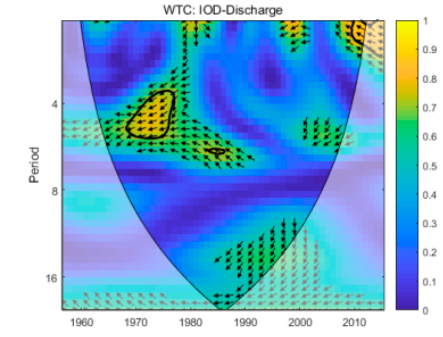

(a3)

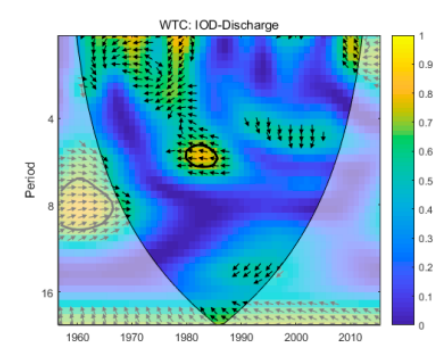

(b3)

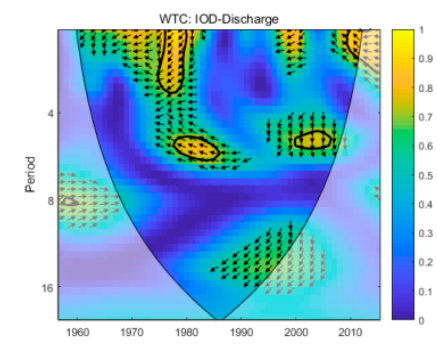

(c3)

Figure 14. Wavelet coherence of discharge of three hydrological stations with MEI, PDO, IOD, respectively. ((a1-a3) Nuxia station; (b1-b3) Nugesha station; (c1-c3) Yangcun station). The meaning in the figure is the same as in Figure 10.

\section{Discussion}

Generally, the test results are characterized by statistically significant increasing trends in temperature and precipitation, a mixture of increasing and decreasing trends in streamflow. To examine the main causes of the changes in air temperature, precipitation, and streamflow in the YLZR basin, we further calculated the circulation map using National Centers for Environmental Prediction /National Center for Atmospheric Research (NCEP/NCAR) reanalysis data during 1957-1970, 1971-1990, and 1991-2015, respectively, to detect the impacts of large-scale circulation changes on precipitation and air temperature. The years 1971-1990 were subtracted from 1957-1970 to detect the changes in circulation between the two periods. The periods 1971-1990 and 1991-2015 were the same as the former (Figure 15). Figure 15a indicated that the study area was controlled by an anomaly low pressure. This kind of atmospheric mode provided a favorable environment for the increasing temperature in the study area. Figure $15 \mathrm{~b}$ indicated that the study area was located around an anomaly high-pressure ridge. This kind of atmospheric mode indicated that the precipitation was slightly lower than Figure 15a and was consistent with Figure 3a. Therefore, a variation of geopotential height, wind speed, and rapid warming contributed to the changes in precipitation. 

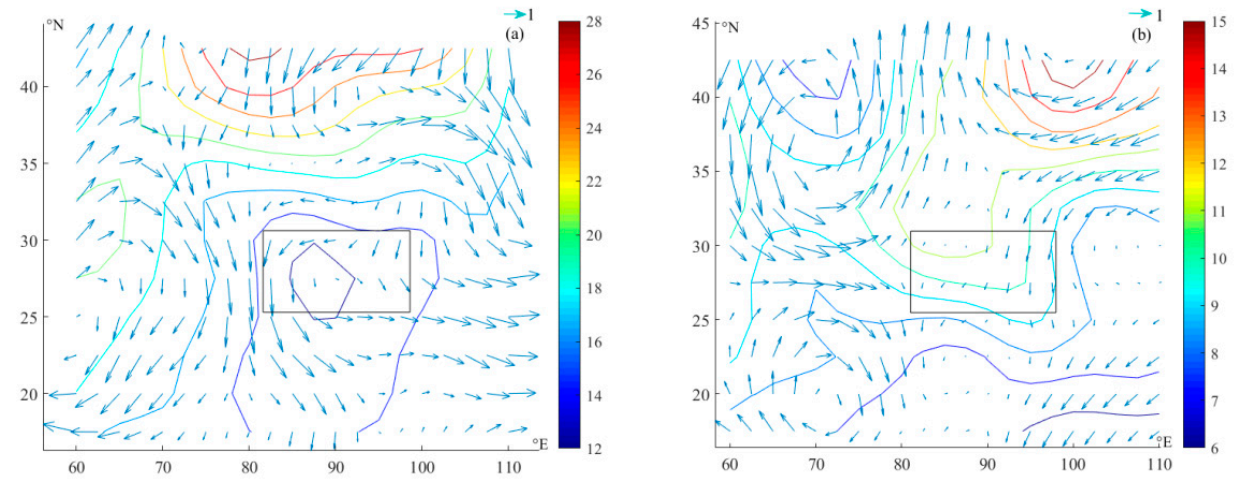

Figure 15. (a) The difference of geopotential height and wind speed (vector) at 500 hpa between 1957-1970 and 1971-1990; (b) the difference of geopotential height and wind speed (vector) at $500 \mathrm{hpa}$ between 1971-1990 and 1991-2015 (the black rectangle is the study area).

The studies showed that the distribution characteristics of precipitation and air temperature of each season were different $[71,72]$. Previous studies have shown that the PDO has an interdecadal regulating effect on global climate change [73]. Generally, precipitation in most areas of China decreases during an El Niño/PDO warm period and increases during a La Niña/PDO cold period, although regional and seasonal differences exist $[74,75]$. Other studies have found that the interannual change of early summer monsoon precipitation in southern China is regulated significantly by the decadal fluctuation of the PDO [76,77], and the relationship between the PDO and precipitation shows instability in the region of the Qinghai-Tibetan Plateau [78]. The response of annual average air temperature to ENSO is weak within the YLZR basin [79]. This study found that the PDO was correlated negatively with annual average precipitation within the YLZR basin at a significant level $(p<0.05)$.

The seasonal rainfall had a great contribution to the annual rainfall and therefore affected the runoff. The abrupt change test result indicated different times that were not were not consistent for temperature, precipitation, and streamflow. The streamflow of different stations showed a similar change point. According to the change point analysis, we can know that the streamflow gauging stations in the late 1960s and the late 1990s were the dominant change times. The rainfall variation had a significant impact on streamflow in the catchment. The trend results showed spatial coherence of three streamflow gauging stations and the annual streamflow for the investigated stations exhibited a mixture of increasing and decreasing trends during 1957-2015.

\section{Conclusions}

In this study, space-time distribution characteristics, trends, abrupt changes, and periods of annual and seasonal precipitation series in the YLZR basin are analyzed during 1957-2015. The following conclusions can be summarized from the above analysis results.

(1) Distribution of precipitation is uneven in space, with more in the southeast. The inter-annual variation of precipitation showed a clear regional and seasonal difference in the YLZR basin. Areal annual precipitation exhibited an increasing trend from 1957 to 2015, which was mainly attributable to increased summer precipitation. Spring precipitation exhibited a significant increasing trend. The change points mainly appeared in the 1970s and 1990s.

(2) Due to the different natural topography, geographical location, and anthropic activities at the gauging stations, the different hydrological stations showed different results of abrupt changes. Under the background of global warming, the precipitation variation of the YLZR basin was influenced by atmospheric circulations, altitude, and anthropic activities.

(3) At different scales, precipitation or temperature changes in advance lagged the atmospheric circulation factor. PDO, MEI, and IOD had same influences on precipitation and temperature.

The mechanism of change of precipitation, air temperature, and streamflow within the YLZR basin is very complicated. This study analyzed only the spatiotemporal variability of hydro-meteorological 
and it correlations with climate indices. Moreover, this study did not consider the impact of human activities and the altitude on the changes of regional precipitation and air temperature. In the future, relevant indicators should be selected for further analysis and the impact of human activities should be analyzed. Related research will provide a scientific theoretical basis for water issues under climate change and help us to improve areal hazard mitigation and water resources management.

Author Contributions: Individual contributions of authors was as follows: Conceptualization, Z.X. and R.Z.; methodology, R.Z.; data processing, R.Z. and C.B.; writing-original draft preparation, R.Z.; writing-review and editing, Z.X. and D.Z. All authors have read and agreed to the published version of the manuscript.

Funding: This research was funded by the National Natural Science Foundation of China, grant number 91647202.

Acknowledgments: The authors would like to thank the editors and the anonymous reviewers for their crucial comments, which helped improve the quality of this paper. The work reported in this paper was supported by the National Natural Science Foundation of China (Grant No. 91647202).

Conflicts of Interest: The manuscript has not been published elsewhere, and it has not been submitted simultaneously for publication elsewhere. We also have no conflicts of interest to disclose. All authors have seen and approved the manuscript and have contributed significantly to the paper.

\section{References}

1. Xu, M.; Kang, S.; Wu, H.; Yuan, X. Detection of spatio-temporal variability of air temperature and precipitation based on long-term meteorological station observations over Tianshan Mountains, Central Asia. Atmos. Res. 2018, 203, 141-163. [CrossRef]

2. Li, Y.; Tao, H.; Su, B.; Kundzewicz, Z.W.; Jiang, T. Impacts of 1.5 degrees $C$ and 2 degrees $C$ global warming on winter snow depth in Central Asia. Sci. Total Environ. 2019, 651 (Pt 2), 2866-2873. [CrossRef]

3. Alford, R.A.; Bradfield, K.S.; Richards, S.J. Ecology: Global warming and amphibian losses. Nature 2007, 447, E3-E4. [CrossRef] [PubMed]

4. McMichael, A.J.; Woodruff, R.E.; Hales, S. Climate change and human health: Present and future risks. Lancet 2006, 367, 859-869. [CrossRef]

5. Greiner, A.; Semmler, W. Economic growth and global warming: A model of multiple equilibria and thresholds. J. Econ. Behav. Organ. 2005, 57, 430-447. [CrossRef]

6. Patz, J.A.; Campbell-Lendrum, D.; Holloway, T.; Foley, J.A. Impact of regional climate change on human health. Nature 2005, 438, 310-317. [CrossRef] [PubMed]

7. Ding, L.; Zhou, J.; Zhang, X.; Liu, S.; Cao, R. Downscaling of surface air temperature over the Tibetan Plateau based on DEM. Int. J. Appl. Earth Obs. Geoinf. 2018, 73, 136-147. [CrossRef]

8. Zhong, R.; He, Y.; Chen, X. Responses of the hydrological regime to variations in meteorological factors under climate change of the Tibetan plateau. Atmos. Res. 2018, 214, 296-310. [CrossRef]

9. New, M.; Todd, M.; Hulme, M.; Jones, P. Precipitation measurements and trends in the twentieth century. Int. J. Climatol. 2001, 21, 1889-1922. [CrossRef]

10. Shi, J.; Cui, L.; Ma, Y.; Du, H.; Wen, K. Trends in temperature extremes and their association with circulation patterns in China during 1961-2015. Atmos. Res. 2018, 212, 259-272. [CrossRef]

11. Blandford, T.R.; Humes, K.S.; Harshburger, B.J.; Moore, B.C.; Walden, V.P.; Ye, H. Seasonal and Synoptic Variations in Near-Surface Air Temperature Lapse Rates in a Mountainous Basin. J. Appl. Meteorol. Climatol. 2008, 47, 249-261. [CrossRef]

12. Mohammed, R.; Scholz, M. The reconnaissance drought index: A method for detecting regional arid climatic variability and potential drought risk. J. Arid Environ. 2017, 144, 181-191. [CrossRef]

13. Shi, P.; Ma, X.; Hou, Y.; Li, Q.; Zhang, Z.; Qu, S.; Fang, X. Effects of Land-Use and Climate Change on Hydrological Processes in the Upstream of Huai River, China. Water Resour. Manag. 2013, 27, 1263-1278. [CrossRef]

14. Sun, Q.; Kong, D.; Miao, C.; Duan, Q.; Yang, T.; Ye, A.; Gong, W. Variations in global temperature and precipitation for the period of 1948 to 2010. Environ. Monit. Assess. 2014, 186, 5663-5679. [CrossRef]

15. Zhou, X.; Zhao, P.; Chen, J.; Chen, L.; Li, W. Impacts of thermodynamic processes over the Tibetan Plateau on the Northern Hemispheric climate. Sci. China Ser. D Earth Sci. 2009, 52, 1679-1693. [CrossRef]

16. You, Q.; Kang, S.; Wu, Y.; Yan, Y. Climate change over the Yarlung Zangbo River Basin during 1961-2005. J. Geogr. Sci. 2007, 17, 409-420. [CrossRef] 
17. Zhang, L.; Su, F.; Yang, D.; Hao, Z.; Tong, K. Discharge regime and simulation for the upstream of major rivers over Tibetan Plateau. J. Geophys. Res. Atmos. 2013, 118, 8500-8518. [CrossRef]

18. Ma, Y.; Lu, M.; Chen, H.; Pan, M.; Hong, Y. Atmospheric moisture transport versus precipitation across the Tibetan Plateau: A mini-review and current challenges. Atmos. Res. 2018, 209, 50-58. [CrossRef]

19. Li, F.; Zhang, Y.; Xu, Z.; Teng, J.; Liu, C.; Liu, W.; Mpelasoka, F. The impact of climate change on runoff in the southeastern Tibetan Plateau. J. Hydrol. 2013, 505, 188-201. [CrossRef]

20. Yang, M.; Wang, X.; Pang, G.; Wan, G.; Liu, Z. The Tibetan Plateau cryosphere: Observations and model simulations for current status and recent changes. Earth Sci. Rev. 2019, 190, 353-369. [CrossRef]

21. Yu, C.Q.; Wang, J.W.; Shen, Z.X.; Fu, G. Effects of experimental warming and increased precipitation on soil respiration in an alpine meadow in the Northern Tibetan Plateau. Sci. Total Environ. 2019, 647, 1490-1497. [CrossRef] [PubMed]

22. Yang, K.; Wu, H.; Qin, J.; Lin, C.; Tang, W.; Chen, Y. Recent climate changes over the Tibetan Plateau and their impacts on energy and water cycle: A review. Glob. Planet. Chang. 2014, 112, 79-91. [CrossRef]

23. Shen, M.; Piao, S.; Jeong, S.J.; Zhou, L.; Zeng, Z.; Ciais, P.; Yao, T. Evaporative cooling over the Tibetan Plateau induced by vegetation growth. Proc. Natl. Acad. Sci. USA 2015, 112, 9299-9304. [CrossRef] [PubMed]

24. Zhang, D.; Huang, J.; Guan, X.; Chen, B.; Zhang, L. Long-term trends of precipitable water and precipitation over the Tibetan Plateau derived from satellite and surface measurements. J. Quant. Spectrosc. Radiat. Transf. 2013, 122, 64-71. [CrossRef]

25. Li, B.; Zhou, W.; Zhao, Y.; Ju, Q.; Yu, Z.; Liang, Z.; Acharya, K. Using the SPEI to Assess Recent Climate Change in the Yarlung Zangbo River Basin, South Tibet. Water 2015, 7, 5474-5486. [CrossRef]

26. Deng, C.; Zhang, W. Spatiotemporal distribution and the characteristics of the air temperature of a river source region of the Qinghai-Tibet Plateau. Environ. Monit. Assess. 2018, 190, 368. [CrossRef]

27. Liu, W.; Xu, Z.; Li, F.; Zhang, L.; Zhao, J.; Yang, H. Impacts of climate change on hydrological processes in the Tibetan Plateau: A case study in the Lhasa River basin. Stoch. Environ. Res. Risk Assess. 2015, 29, 1809-1822. [CrossRef]

28. Liu, Z.; Yao, Z.; Huang, H.; Wu, S.; Liu, G. Land Use and Climate Changes and Their Impacts on Runoff in the Yarlung Zangbo River Basin, China. Land Degrad. Dev. 2014, 25, 203-215. [CrossRef]

29. Zhang, W.; Zhang, L.; Zhou, T. Interannual variability and the underlying mechanism of summer precipitation over the Yarlung Zangbo River basin. Chin. J. Atmos. Sci. 2016, 40, 965-980. (In Chinese)

30. Liu, J.; Zhang, W.; Liu, T.; Li, Q. Runoff Dynamics and Associated Multi-Scale Responses to Climate Changes in the Middle Reach of the Yarlung Zangbo River Basin, China. Water 2018, 10, 295. [CrossRef]

31. Li, D.; Li, J.; Zhang, L.; Deng, Y.; Zhang, Y. Variations in the key hydrological elements of the Yarlung Zangbo River Basin. Water Sci. Technol. Water Supply 2018. [CrossRef]

32. Nie, N.; Zhang, W.C.; Deng, C. Responses of water resource of the Yarlung Zangbo River Basin to climate changes and glacier-snow fluctuations in recent years. IOP Conf. Ser. Earth Environ. Sci. 2016, 46, 012042. [CrossRef]

33. Gao, J.; Williams, M.W.; Fu, X.; Wang, G.; Gong, T. Spatiotemporal distribution of snow in eastern Tibet and the response to climate change. Remote Sens. Environ. 2012, 121, 1-9. [CrossRef]

34. Liu, Z.; Wang, R.; Yao, Z. Climate change and its impact on water availability of large international rivers over the mainland Southeast Asia. Hydrol. Process. 2018, 32, 3966-3977. [CrossRef]

35. Ding, L.; Zhou, L.; Zhang, X.; Liu, S.; Cao, R. A long-term 0.01 degrees surface air temperature dataset of Tibetan Plateau. Data Brief 2018, 20,748-752. [CrossRef]

36. Wang, T.; Miao, J.-P.; Sun, J.-Q.; Fu, Y.-H. Intensified East Asian summer monsoon and associated precipitation mode shift under the $1.5^{\circ} \mathrm{C}$ global warming target. Adv. Clim. Chang. Res. 2018, 9, 102-111. [CrossRef]

37. Wu, R.; Hu, Z.Z. Evolution of ENSO-Related Rainfall Anomalies in East Asia. J. Clim. 2003, 16, 3742-3758. [CrossRef]

38. Shen, C.; Wang, W.C.; Gong, W.; Hao, Z. A Pacific Decadal Oscillation record since 1470 AD reconstructed from proxy data of summer rainfall over eastern China. Geophys. Res. Lett. 2006, 33. [CrossRef]

39. Li, S.; Bates, G.T. Influence of the Atlantic Multidecadal Oscillation on the winter climate of East China. Adv. Atmos. Sci. 2007, 24, 126-135. [CrossRef]

40. Li, H.; Jiang, Z.; Yang, Q. Association of North Atlantic Oscillations with Aksu River runoff in China. J. Geog. Sci. 2009, 19, 12-24. [CrossRef] 
41. Liu, Y.; Wang, L.; Zhou, W.; Chen, W. Three Eurasian teleconnection patterns: Spatial structures, temporal variability, and associated winter climate anomalies. Clim. Dyn. 2014, 42, 2817-2839. [CrossRef]

42. Ding, Y.; Liu, Y.; Liang, S.; Ma, X.; Zhang, Y.; Si, D.; Liang, P.; Song, Y.; Zhang, J. Interdecadal variability of the East Asian winter monsoon and its possible links to global climate change. Acta Meteorol. Sin. 2014, 72, 835-852. [CrossRef]

43. Shi, S.; Li, J.; Shi, J.; Zhao, Y.; Huang, G. Three centuries of winter temperature change on the southeastern Tibetan Plateau and its relationship with the Atlantic Multidecadal Oscillation. Clim. Dyn. 2016, 49, 1305-1319. [CrossRef]

44. Wang, J.; Yang, B.; Qin, C.; Kang, S.; He, M.; Wang, Z. Tree-ring inferred annual mean temperature variations on the southeastern Tibetan Plateau during the last millennium and their relationships with the Atlantic Multidecadal Oscillation. Clim. Dyn. 2013, 43, 627-640. [CrossRef]

45. Feng, S.; Hu, Q. How the North Atlantic Multidecadal Oscillation may have influenced the Indian summer monsoon during the past two millennia. Geophys. Res. Lett. 2008, 35. [CrossRef]

46. Hartmann, H.; Becker, S.; King, L. Predicting summer rainfall in the Yangtze River basin with neural networks. Int. J. Climatol. 2008, 28, 925-936. [CrossRef]

47. Fang, K.; Gou, X.; Chen, F.; Li, J.; D'Arrigo, R.; Cook, E.; Yang, T.; Davi, N. Reconstructed droughts for the southeastern Tibetan Plateau over the past 568 years and its linkages to the Pacific and Atlantic Ocean climate variability. Clim. Dyn. 2009, 35, 577-585. [CrossRef]

48. Halpert, M.S.; Ropelewski, C.F. Surface Temperature Patterns Associated with the Southern Oscillation. Climate 1992, 5, 577-593. [CrossRef]

49. Liu, J.; Xu, Z.; Bai, J.; Peng, D.; Ren, M. Assessment and Correction of the PERSIANN-CDR Product in the Yarlung Zangbo River Basin, China. Remote Sens. 2018, 10, 2031. [CrossRef]

50. Sun, W.; Wang, Y.; Fu, Y.H.; Xue, B.; Wang, G.; Yu, J.; Zuo, D.; Xu, Z. Spatial heterogeneity of changes in vegetation growth and their driving forces based on satellite observations of the Yarlung Zangbo River Basin in the Tibetan Plateau. J. Hydrol. 2019, 574, 324-332. [CrossRef]

51. Liu, X.; Ren, Z. Progress in quality control of surface meteorological data. Meteorol. Sci. Technol. 2005, 33, 199-203.

52. Erxleben, J.; Elder, K.; Davis, R. Comparison of spatial interpolation methods for estimating snow distribution in the Colorado Rocky Mountains. Hydrol. Process. 2002, 16, 3627-3649. [CrossRef]

53. Liu, S.; Su, H.; Tian, J.; Zhang, R.; Wang, W.; Wu, Y. Evaluating Four Remote Sensing Methods for Estimating Surface Air Temperature on a Regional Scale. J Appl. Meteorol. Clim. 2017, 56, 803-814. [CrossRef]

54. Mann, H.B. Nonparametric Tests Against Trend. Econometrica 1945, 13, 245-259. [CrossRef]

55. Kendall, M.G. Rank Correlation Methods; Charles Griffin: London, UK, 1975.

56. Sen, P.K. Estimates of the Regression Coefficient Based on Kendall's Tau. J. Am. Stat. Assoc. 1968, 63, 1379-1389. [CrossRef]

57. Gocic, M.; Trajkovic, S. Spatiotemporal characteristics of drought in Serbia. J. Hydrol. 2014, 510, 110-123. [CrossRef]

58. Ahmadalipour, A.; Moradkhani, H.; Demirel, M.C. A comparative assessment of projected meteorological and hydrological droughts: Elucidating the role of temperature. J. Hydrol. 2017, 553, 785-797. [CrossRef]

59. Jiang, R.; Wang, Y.; Xie, J.; Zhao, Y.; Li, F.; Wang, X. Assessment of extreme precipitation events and their teleconnections to El Niño Southern Oscillation, a case study in the Wei River Basin of China. Atmos. Res. 2019, 218, 372-384. [CrossRef]

60. Ren, M.; Pang, B.; Xu, Z.; Yue, J.; Zhang, R. Downscaling of daily extreme temperatures in the Yarlung Zangbo River Basin using machine learning techniques. Theor. Appl. Climatol. 2018. [CrossRef]

61. Zheng, J.; Peng, S.; Liu, M.; Liang, Z. A novel seismic wavelet estimation method. J. Appl. Geophys. 2013, 90, 92-95. [CrossRef]

62. Kang, S.; Lin, H. Wavelet analysis of hydrological and water quality signals in an agricultural watershed. J. Hydrol. 2017, 338, 1-14. [CrossRef]

63. Partal, T. Wavelet based periodical analysis of the precipitation data of the Mediterranean Region and its relation to atmospheric indices. Modeling Earth Syst. Environ. 2018, 4, 1309-1318. [CrossRef]

64. Tamaddun, K.A.; Kalra, A.; Ahmad, S. Wavelet analysis of western US streamflow with ENSO and PDO. J. Water Clim. Chang. 2016, 8, 26-39. [CrossRef] 
65. Grinsted, A.; Moore, J.C.; Jevrejeva, S. Application of the cross wavelet transform and wavelet coherence to geophysical time series. Nonlinear Process. Geophys. 2004, 11, 561-566. [CrossRef]

66. Torrence, C.; Compo, G.P. A Practical Guide to Wavelet Analysis. Bull. Am. Meteorol. Soc. 1998, 79, 61-78. [CrossRef]

67. Fang, K.; Chen, F.; Sen, A.K.; Davi, N.; Huang, W.; Li, J.; Seppä, H. Hydroclimate Variations in Central and Monsoonal Asia over the Past 700 Years. PLoS ONE 2014, 9, e102751. [CrossRef]

68. Matyasovszky, I. Detecting abrupt climate changes on different time scales. Appl. Clim. 2011, 105, 445-454. [CrossRef]

69. Hennessy, K.J.; Gregory, J.M.; Mitchell, J.F.B. Changes in daily precipitation under enhanced greenhouse conditions. Dyn. Clim. 1997, 13, 667-680. [CrossRef]

70. Berg, P.; Haerter, J.O.; Thejll, P.; Piani, C.; Hagemann, S.; Christensen, J.H. Seasonal characteristics of the relationship between daily precipitation intensity and surface temperature. J. Geophys. Res. 2009, 114. [CrossRef]

71. You, Q.; Kang, S.; Aguilar, E.; Pepin, N.; Flügel, W.A.; Yan, Y.; Xu, Y.; Zhang, Y.; Huang, J. Changes in daily climate extremes in China and their connection to the large scale atmospheric circulation during 1961-2003. Clim. Dyn. 2010, 36, 2399-2417. [CrossRef]

72. Zhang, W.; Pan, S.; Cao, L.; Cai, X.; Zhang, K.; Xu, Y.; Xu, W. Changes in extreme climate events in eastern China during 1960-2013: A case study of the Huaihe River Basin. Quat. Int. 2015, 380, 22-34. [CrossRef]

73. Kim, J.; Yeh, S.; Chang, E. Combined effect of El Niño-Southern Oscillation and Pacific Decadal Oscillation on the East Asian winter monsoon. Clim. Dyn. 2013, 42, 957-971. [CrossRef]

74. Ouyang, R.; Liu, W.; Fu, G.; Liu, C.; Hu, L.; Wang, H. Linkages between ENSO/PDO signals and precipitation, streamflow in China during the last 100 years. Hydrol. Earth Syst. Sci. 2014, 18, 3651-3661. [CrossRef]

75. Ma, Z.; Shao, L. Relationship between dry_wet variation and the Pacific Decade Oscillation (PDO) in northern China during the last 100 years. Chin. J. Atmos. Sci. 2006, 30, 464-474. (In Chinese)

76. Chan, J.C.L. PDO, ENSO and the early summer monsoon rainfall over south China. Geophys. Res. Lett. 2005, 32. [CrossRef]

77. Mao, J.; Chan, J.C.L.; Wu, G. Interannual variations of early summer monsoon rainfall over South China under different PDO backgrounds. Int. J. Climatol. 2011, 31, 847-862. [CrossRef]

78. Gou, X.; Deng, Y.; Chen, F.; Yang, M.; Gao, L.; Nesje, A.; Fang, K. Precipitation variations and possible forcing factors on the Northeastern Tibetan Plateau during the last millennium. Quat. Res. 2017, 81, 508-512. [CrossRef]

79. Xu, H.; Hong, Y.; Hong, B.; Zhu, Y.; Wang, Y. Influence of ENSO on multi-annual temperature variations at Hongyuan, NE Qinghai-Tibet plateau: Evidence from $\delta 13 \mathrm{C}$ of spruce tree rings. Int. J. Climatol. 2010, 30, 120-126. [CrossRef]

(C) 2020 by the authors. Licensee MDPI, Basel, Switzerland. This article is an open access article distributed under the terms and conditions of the Creative Commons Attribution (CC BY) license (http://creativecommons.org/licenses/by/4.0/). 